\title{
Case report of dystrophic epidermolysis bullosa confirmed by genetic analysis
}

\section{Opis przypadku epidermolysis bullosa w postaci dystroficznej potwierdzonego w analizie genetycznej}

\author{
Danielius Serapinas ${ }^{1,2}$, Egle Aukstuoliene ${ }^{3}$, Marius Sukys ${ }^{2}$ \\ Institute of Psychology, Mykolas Romeris University, Vilnius, Lithuania \\ Head of the Institute: Prof. Rita Bandzeviciene PhD \\ ${ }^{2}$ Medical Academy, Lithuanian University of Health Sciences, Kaunas, Lithuania \\ Head of the Academy: Prof. Remigijus Zaliunas MD, PhD \\ ${ }^{3}$ Clinic of Infectious and Chest Diseases, Dermatovenereology and Allergology, Vilnius University Faculty of Medicine, Vilnius, Lithuania \\ Head of the Department: Prof. Matilda Bylaite Bucinskiene MD, PhD
}

Key words: epidermolysis bullosa, mutation, COL7A1 gene.

Słowa kluczowe: epidermolysis bullosa, mutacja, gen COL7A1.

\begin{abstract}
Dystrophic epidermolysis bullosa is an inherited disease presenting with blistering of the skin in the subdermal layer caused by gene COL7A1 mutations. The authors reviewed a case of this disease determined by two mutations: dominant and recessive. The disease presented with blisters all over the patient's body, mostly on the neck, back, and inguinal area, as well as on the hands and feet. The symptom that most affected the patient's quality of life was severe blistering and ulceration in the pharynx, mucous membrane of the mouth, and perianal area. There is no effective treatment today, only procedures to relieve complications like oesophageal obstructions.
\end{abstract}

\section{Streszczenie}

Postać dystroficzna pęcherzowego oddzielania się naskórka (epidermolysis bullosa) to choroba dziedziczna objawiająca się powstawaniem pęcherzy na skórze, w warstwie podskórnej wywołanym mutacjami genu COL7A1. W pracy przedstawiono przypadek tej choroby zdeterminowany dwoma mutacjami - dominującą i recesywną. Choroba objawiła się wystąpieniem pęcherzy na całym ciele pacjenta, głównie na szyi, plecach, w rejonie pachwin oraz na rękach i stopach. Największy wpływ na jakość życia pacjenta miało powstawanie uciążliwych pęcherzy oraz owrzodzenie w obrębie gardła, błony śluzowej jamy ustnej oraz w rejonie odbytu. Obecnie nie ma skutecznej metody leczenia, stosuje się jedynie zabiegi mające na celu złagodzenie powikłań, takich jak niedrożność przełyku.

\section{Introduction}

Epidermolysis bullosa (EB) is a group of hereditary diseases that present by the formation of blisters and erosions on the skin and mucous membranes caused by minimal traction or trauma [1]. Currently EB is classified into four major types according to the location of the lesions: epidermolysis bullosa simplex in the epidermis, junctional EB within lamina lucida of the skin base membrane, dystrophic EB in the uppermost dermis, and Klinder syndrome in multiple layers of the skin [2]. Dystrophic EB (DEB) is a rather rare disease (seven cases per million) that does not have a good therapy developed yet [3].

\section{Case report}

The 2-month-old female (born July 2005) patient was suspected of recessive dystrophic epidermolysis bullosa (RDEB) at the Lithuanian Health Science University Hospital Genetic Counselling room since her birth because of dystrophic EB blistering. Both parents of the patient are healthy and non-consanguineous. The patient has no siblings.

The first symptoms, skin and mouth blistering, appeared since birth. After starting breastfeeding, painful mouth ulceration appeared. These ulcers healed slowly leaving scar tissue. At the age of 1 year, she started getting constipations. This resulted in severe painful peri- 
anal ulceration. Up to 2 years old, the most affected areas were the mouth, the perianal area, and the skin. A skin biopsy was performed and the histological examination revealed sub-epidermal blistering. Since she turned 2 years old, swallowing problems occurred because of the ulcers and blisters started to show in the oesophagus and pharynx. As the ulcers started to heal, the scar tissue formed strictures and spasms in the oesophagus, leading to complete occlusion. Regularly (4-5 times per year) the patient was hospitalised for endoscopy and treatment procedures to open the oesophagus. At the same time, a tendency for constipation persisted, and sometimes severe constipation with faecal impaction appeared, despite of the fact that her parents were well informed and very careful about cleaning out and not allowing the patient to have stools less than twice a week. Her teeth maintained good health because she regularly received prophylactic procedures since she was 6 months old.

During the last examination in 2012, the patient was reasonably healthy. She had many ruptured blisters all over her body, mostly on her neck, back, and inguinal area, as well as on her hands and feet. The condition that most affected her quality of life was the severe blistering and ulceration in her pharynx and mucous membrane of the mouth. These lesions interfered with chewing and swallowing. Additionally, the patient was suffering from a temporomandibular joint contracture. Due to that she could hardly open her mouth enough to take a spoonful. Furthermore, the patient had lost her toenails. But her hands were almost normally preserved due to continuous wearing of gloves since 4 months of age: she lost only one fingernail, and there was no finger fusion. Her nutrition state was satisfactory for her age. Weight $-21 \mathrm{~kg}$, height $-125 \mathrm{~cm}\left(\mathrm{Wt} / \mathrm{Ht}\right.$ ratio $-10^{\text {th }}$ percentile). Her organ systems were within normal limits.

Despite these conditions, the patient was relatively healthy, only affected by common paediatric diseases. Up to 1 year old, the patient had herpes simplex stomatitis and mild obstructive bronchitis a few times. At 6 years old she was infected by group A $\beta$-haemolytic streptococcus. High temperature, suppuration of blisters, and lymphadenitis were observed. The laboratory findings showed high white blood cell count and C-reactive protein. The Infection was successfully treated with intravenous ceftriaxone for 7 days. The folowing year she had recurrent eye problems with conjunctivitis, which were managed without corneal scarring.

During the whole period of observation the patient never had blistering on her cheeks and gluteal area. This phenomenon allowed the authors to suggest that she might be one of those rare patients of RDEB with essential mosaicism. To prove the diagnosis of RDEB, a DNR sample was sent to the Centre for Human Genetics for molecular genetic analysis of the COL7A1 gene. Mutations c.425A > G in exon 3 (causing a recessive dystrophic epidermolysis bullosa) and
c.6007G > C, p.G2003R, in exon 73 of the COL7A1 gene (causing a dominant dystrophic Epidermolysis bullosa); each were found in a heterozygous state.

\section{Discussion}

Epidermolysis bullosa represents a heterogeneous group of mechanobullous diseases that are characterised by the formation of blisters and erosions on skin and mucous membranes following minor traction or trauma $[2,4]$. This group is classified in to four types of EB: EB simplex, junctional EB, DEB, and Klinder syndrome.

Dystrophic EB is mainly caused by mutations in the gene COL7A1 located in the third chromosome's short arm, which codes the $\alpha$ chain of VII type collagen, a component of the anchoring fibrils at the dermal-epidermal junction. Because the lesion is below the cutaneous basement membrane, wound healing is often presented with scar tissue [1]. There are several subtypes of EBD, mainly categorised by heredity: dominant and recessive autosomal.

Mechanical fragility is the most common feature of EB. Due to this, tense blisters filled with clear exudate may form. Other typical findings are milia, dystrophy, or the absence of nails, exuberant granulation of tissue, congenital absence of skin, palmoplantar keratoderma, and mottled pigmentation [1].

Dominant dystrophic epidermolysis bullosa (DDEB) has reduced expression of type VII collagen and has relatively better prognosis than other EB types [5]. Typically lesions occur due to trauma resulting in scarring, milia formation, and loss of nails [2]. Also, due to the blistering of the oesophagus, it can form oesophageal stenosis [2]. The previously mentioned mutation c.6007G $>\mathrm{C}$ is thought to cause Bart's syndrome [6]. Bart's syndrome manifests as congenital absence of skin and typical EB symptoms [1]. The absence of a skin appears from birth, but this was not observed in the author's case.

In RDEB, blistering begins soon after birth and can occur spontaneously. Mostly the eyes, teeth, mouth, and oesophagus are affected, as well as blistering of the skin. Severe scarring occurs as the blisters heal, leading to hand deformities and obstruction of the esophagus [1]. The found mutation in this case c. $425 \mathrm{~A}>\mathrm{G}$ (Lys142Arg) in exon 3 has been reported in dystrophic epidermolysis bullosa inversa but with another mutation, Arg2069Cys, in exon 74 [7]. Studies show that the inversa type is caused mostly by substitution of arginin or glycin, so it is difficult to tell if lys142arg causes the inversa subtype [8]. Other data shows that this mutation mainly appears in severe generalised RDEB [9].

It has been reported that certain types of DEB have an increased risk of squamous cell carcinoma (SSC). The highest risk is of the RDEB HS subtype (26\%) [1]. One study suggests that patients with RDEB 
have a higher risk of SSC due to the expression of type VII collagen, especially the NC1 domain, which forms the bundles of anchoring fibrils and provides stability to the cutaneous basement membrane zone [10]. Nevertheless, this hypothesis was denied [11].

If $\mathrm{EB}$ is suspected in a patient, recommendations suggest first identifying the level of skin cleavage. This can be done by immunofluorescence antigen mapping or electron microscopy on newly induced blisters. In order to correctly diagnose the disease, mutational analysis is recommended, if available and affordable [2]. This will enable further treatment in the future if gene therapy is established because today there is no effective therapy or cure for EB [12].

Currently, as mentioned above, there is no effective therapy or cure for EB. But huge steps have been taken towards new treatments during the last decade, such as gene therapy, protein replacement therapy, cell therapies, culturing revertant mosaic keratinocytes, gene engineering, and clinical application of inducible pluripotent stem cells [12, 13]. It has been shown that protein replacement of large structural proteins such as collagens is possible and can attenuate the mucocutaneous manifestations of the generalised severe recessive dystrophic epidermolysis bullosa [14]. There have been reported clinical trials that have initiated stem cells transplantations from bone marrow in the treatment of patients with RDEB. The results are promising but yet not final [1]. New potential has been shown in gene therapy, which focuses on the virally mediated ex vivo correction of autologous epithelium. These corrected cells are expanded and grafted on the patient. But there are limitations applying these cells because it is difficult to apply them on mucous membranes [15].

Inherited EB has various phenotypes depending on which layer of the skin is involved in the pathological process. Moreover, the clinical features are very different even for the same type of $\mathrm{EB}$, so it is important to identify the site of mutation. This allows the complications of the disease to be foreseen and prophylactic procedures to be carried out before they develop.

\section{Conflict of interest}

The authors declare no conflict of interest.

\section{References}

1. Fine JD. Inherited epidermolysis bullosa: past, present, and future. Ann N Y Acad Sci 2010; 1194: 213-22.

2. Fine JD, Bruckner-Tuderman L, Eady RA, et al. Inherited epidermolysis bullosa: updated recommendations on diagnosis and classification. J Am Acad Dermatol 2014; 70: 1103-26.

3. Davila-Seijo P, Hernández-Martin A, Morcillo-Makow E, et al. Prioritization of therapy uncertainties in dystrophic epidermolysis bullosa: where should research direct to? an example of priority setting partnership in very rare disorders. Orphanet J Rare Dis 2013; 8: 61.

4. QueirozFuscaldi LAN, Buçard AM, Alvarez CDQ, Barcaui $\mathrm{CB}$. Epidermolysis bullosa nevi: report of a case and review of the literature. Case Rep Dermatol 2011; 3: 235-9.

5. Frew JW, Martin LK, Nijsten T, Murrell DF. Quality of life evaluation in epidermolysis bullosa (EB) through the development of the QOLEB questionnaire: an EB-specific quality of life instrument. Br J Dermatol 2009; 161: 1323-30.

6. Christiano AM, Bart BJ, Epstein EH, Uitto J. Genetic basis of Bart's syndrome: a glycine substitution mutation in type VII collagen gene. J Invest Dermatol 1996; 106: 778-80.

7. Kahofer K, Bruckner-Tuderman L, Metze D, et al. Dystrophic Epidermolysis bullosa inversa with COL7A1 mutations and absence of GDA-J/F3 protein. Pediatr Dermatol 2003; 20: 243-8.

8. Akker P, Mellerio JE, Martinez AE, et al. The inversa type of recessive dystrophic epidermolysis bullosa is caused by specific arginine and glycine substitutions in type VII collagen. J Med Genet 2011; 48: 160-7.

9. Jerabkova B, Kopeckova L, Buckova H, et al. Analysis of the COL7A1 gene in Czech patients with dystrophic epidermolysis bullosa reveals novel and recurrent mutations. J Dermatol Sci 2010; 59: 136-40.

10. Ortiz-Urda S, Garcia J, Green CL, et al. Type VII collagen is required for Ras-driven human epidermal tumorogenesis. Science 2005; 307: 1773-6.

11. Pourreyron C, Cox G, Mao1 X, et al. Patients with recessive dystrophic epidermolysis bullosa develop squamous-cell carcinoma regardless of tpe VII collagen expression. J Investig Dermatol 2007; 127: 2438-44.

12. Hsu CK, Wang SP, Lee JY, McGrath JA. Treatment of hereditary epidermolysis bullosa: updates and future prospects. Am J Clin Dermatol 2014; 15: 1-6.

13. Lees CJ, Eide C, Keene DR, et al. Patient-specific naturally gene-reverted induced pluripotent stem cells in recessive dystrophic epidermolysis bullosa. J Invest Dermatol 2014; 134: 1246-54.

14. Tolar J, Wagner JE. Allogeneic blood and bone marrow cells for the treatment of severe epidermolysis bullosa: repair of the extracellular matrix. Lancet 2013; 382: 1214-23.

15. Cutlar L, Greiser U, Wang W. Gene therapy: pursuing restoration of dermal adhesion in recessive dystrophic epidermolysis bullosa. Exp Dermatol 2014; 23: 1-6.

\section{Address for correspondence:}

Danielius Serapinas PhD

Institute of Psychology

Mykolas Romeris University

Ateities 20, LT-08303 Vilnius, Lithuania

Phone: +37 061490479

E-mail: dserapinas@gmail.com 